\title{
'It'll never happen to me': understanding public awareness of local flood risk
}

Kate Burningham, Senior Lecturer Centre for Environmental Strategy, University of Surrey, UK, Jane Fielding, Senior Lecturer, Department of Sociology, University of Surrey, UK, and Diana Thrush, Research fellow, Department of Sociology, University of Surrey, UK

Following the severe flood events of 1998 and 2000, the United Kingdom's Environment Agency prioritised the need to increase public flood risk awareness. Drawing on data collected during research undertaken for the Environment Agency, this paper contributes to understanding of one aspect of flood awareness: people's recognition that their property is in an area that is potentially at risk of flooding. Quantitative analyses indicate that class is the most influential factor in predicting flood risk awareness, followed by flood experience and length of residence. There are also significant area differences. Our qualitative work explores how those defined as 'at risk' account for their lack of awareness or concern about their risk status. We conclude that the problem is often not simply a lack of awareness, but rather, assessments of local risk based on experience that underestimate the impact of rare or extreme events. We underline the importance of engaging with local perspectives on risk and making local people part of 'awareness-raising' processes.

\section{Keywords: flood awareness; disaster response, local knowledge}

\section{Introduction}

Flood risk is an issue of mounting concern in the United Kingdom. In England and Wales alone, some five million people and two million properties are defined as being in areas at risk of flooding. ${ }^{1}$ Add to this the prediction that localised

\footnotetext{
${ }^{1}$ See the website of the Environment Agency, http://www.environment-agency.gov.uk/subjects/flood/?lang=_e (accessed 12 May 2006).
} 
flooding in England and Wales may increase by up to four-fold ${ }^{2}$ by the 2080s and the potential scale of social and economic disruption becomes all too clear. The problem is of considerable concern to the Environment Agency, which, since the severe flood events of 1998 and 2000, has placed a high priority on the need to raise public awareness of flood risk. As Baroness Young, the Chief Executive of the Environment Agency, commented in October 2005:

There is still a significant flood threat here from extreme rainfall and coastal surges ... Devastating floods do happen here too, like those in Autumn 2000, and more recently in Boscastle and Carlisle. There's a tendency for people to think 'it'll never happen to me'. The fact is, it could, we just don't know when. People in this country cannot afford to be complacent about flood risk. ${ }^{3}$

To develop effective flood risk communication strategies, there is a need for better understanding of the factors that influence flood awareness and of how the risk of flooding is constructed by those deemed as 'at risk'. This paper draws on research from two studies conducted in 2001 for the Environment Agency for England and Wales and illustrates the different insights into flood awareness provided by quantitative and qualitative research methods.

\section{Background}

The UK government's policy for flood and coastal defence-implemented by the Ministry of Agriculture, Fisheries and Food (MAFF) until 2001 and now by the Department for Food, Environment and Rural Affairs (Defra)-aims to reduce the risks to people and the developed and natural environment posed by flooding and erosion (MAFF, 1993). Ensuring that the public is aware of flood risk and knows how to act on receipt of a flood warning plays a crucial part in achieving this goal. The Environment Agency targets those at risk of flooding through 'awareness campaigns', involving a wide range of activities, such as direct local

\footnotetext{
${ }^{2}$ See the website of Foresight, http://www.foresight.gov.uk/Previous_Projects/Flood_and_Coastal_Defence/index.html (accessed 12 May 2006)

${ }^{3}$ See. http://www.direct.gov.uk/en/NI1/Newsroom/DG_10026588
} 
engagement with those at risk, media campaigns, publication of flood maps, and dissemination of flood warning letters and pamphlets. From the Environment Agency's perspective, 'the public should be aware of the flood risk, and education and awareness raising is needed to achieve this objective' (Ramsbottom, 2003, p.x).

Flood risk awareness comprises several components:

- awareness of living in an at-risk area;

- awareness of flood warning systems, codes and methods of dissemination; and

- awareness of appropriate action to take in the event of a flood or flood warning.

Estimates of the success of Environment Agency campaigns to raise flood awareness vary. One Environment Agency source claims that there has been 'a big increase in awareness since 2000 , with around $80 \%$ in a flood risk area being aware of the risk of flooding' (Defra 2005). Another, though, worries that 'five million people in two million properties in England and Wales live in flood risk areas, yet despite this, Environment Agency research indicates that as many as two fifths (41\%) of these people nationally are still unaware of the threat'. ${ }^{4}$ Research is needed that defines 'awareness' more clearly and goes beyond the headline figures to reveal whether members of certain social groups are more likely than others to express low levels of awareness, in a bid to explain any patterns found.

The Environment Agency approach to public flood awareness identifies the percentage of the members of the 'at-risk' population who are unaware of the threats to themselves and then seeks to educate them through awareness

\footnotetext{
${ }^{4}$ Closer inspection of the texts reveals that the figures vary depending on how (and where) awareness is being measured. See http://www.direct.gov.uk/en/NI1/Newsroom/DG_10026588 (accessed 7 November 2007).
} 
campaigns; as such, it implicitly adopts a 'deficit model' of public understanding (Wynne, 1991). The assumption is that people lack accurate information and if this were to be provided their awareness deficit would be met. This view of public understanding or awareness has met with extensive sociological criticism. Rather than viewing publics as passive receivers of expert knowledge, they might better be depicted as active citizens who evaluate the multiple sources of knowledge to which they are exposed and who often have valid and useful lay knowledge (see Brown, 1993; Wynne, 1996; Irwin, 1995; Irwin and Michael, 2003). The deficit perspective of public knowledge might be usefully contrasted with a 'contextualist perspective' (Sturgis and Allum, 2004), which emphasises the way in which expert information is likely to be evaluated within 'varying practical and social contexts' (Sturgis and Allum, 2004, p. 75). For instance, publics are likely to appraise information on flood risk in the context of factors such as their experience of floods and their degree of trust in those who supply them with such information.

To incorporate this perspective into the field of flood risk research would mean exploring how those identified as living with such risk construct, understand and respond to it. Social research into a variety of environmental risks routinely highlights ways in which expert and public assessments of risk differ. Differences are often observed in terms of the relative significance accorded to different sources of risk, the magnitude of the risks, their possible impacts, and appropriate responses. Studies indicate that assessments of risk made from 'above' and 'outside' are frequently contested or rejected within localities designated as risky. People identified as 'at risk' often resent the stigmatisation of themselves as vulnerable and their neighbourhoods as risky because such labels can have negative social and material consequences (Burningham and Thrush, 2001; Phillimore and Moffatt, 1999). While existing research has largely focused on those living with the risk of pollution, some of the observations about living with risk may also hold true for those identified as living with a risk of flooding. For instance, the Environment Agency sees flood risk as one of the defining 
characteristics of an area, whereas this may not even register as a significant feature of the place among local residents when viewed in the context of everyday life there (Burningham and Thrush, 2004; House and Fordham, 1997).

Developing a better understanding of how local people understand flood risk and account for their flood 'awareness' might make a critical contribution to awareness campaigns. Risk communication research clearly indicates that it is those campaigns that reflect social values and perspectives that are likely to be the most effective (Shaw et al., 2005).

\section{Methodology}

This paper presents an analysis of quantitative and qualitative data collected during two projects conducted for the Environment Agency in order to begin to develop a more detailed understanding of flood awareness in England and Wales.

Most of the data discussed has its origins in a project entitled 'Flood Warning for Vulnerable Groups' (Burningham et al., 2005), which aimed to create a detailed understanding of whether some groups within the population are particularly vulnerable to floods. This paper draws on secondary analysis of existing survey data and qualitative research conducted as part of this project. The secondary analysis is of the 2001 'At Risk' Survey conducted by the British Market Research Bureau (BMRB) for the Environment Agency. ${ }^{5}$ These annual surveys sample respondents who have been designated as 'at risk' of flooding by the Environment Agency, although they may not have experienced a flood event during their time of residence in their homes. The qualitative data come from focus groups and in-depth interviews with four categories of people (new residents, older people, parents of young children, and disabled people), all living in areas that suffered severe flooding in autumn $2000 .{ }^{6}$ We also examined the

\footnotetext{
${ }^{5}$ See Fielding et al. (2005a) for further details of the methodology.

${ }^{6}$ See Thrush, Burningham and Fielding (2005) for further details of the methodology.
} 
verbatim responses provided in the 2001 Post Event Survey-these are administered after flood events to people whose homes are in areas that have been flooded. Once again, these surveys sample those people 'at risk' in areas that have recently experienced a flood event, but may not actually have been flooded.

In addition, we present some data collected during a subsequent project for the Environment Agency entitled 'Public Response to Flood Warning' (Fielding et al., 2007, which aimed to develop detailed knowledge of how the 'at flood risk' public understands and responds to flood warnings and to comprehend fully their priorities on receipt of a warning. The data from this project discussed here come from focus groups and semi-structured interviews carried out with members of the 'at-risk' public, including those already affected by flooding and those at risk but who have not yet experienced flooding. ${ }^{7}$

While we did not concentrate specifically in these projects on public flood awareness, we did collect a wealth of data pertinent to this topic. In both projects, we examined information relating to awareness of living in a flood risk area and of the danger to one's own property, and awareness of warning codes and how to respond appropriately to flood warnings. Our focus here is on just one dimension of flood awareness: people's awareness that their property is in an area potentially at risk of flooding.

First, we use quantitative analyses to learn more about the social distribution of such awareness. Second, we consider findings from our qualitative work to shed light on how people account for their lack of awareness that their property was or is at risk of flooding.

\section{The social distribution of flood awareness in England and Wales}

\footnotetext{
${ }^{7}$ See Fielding et al. (2007) for details of the methodology.
} 
For the Flood Warning for Vulnerable Groups project, the concept of vulnerability was addressed in three distinct ways:

- in terms of certain groups being more likely than others to live in areas at risk of flooding;

- in terms of certain groups being less likely than others to be aware of their flood risk and of flood warnings; and

- in terms of certain groups being less able than others to respond to flood warnings and to cope with a flood event.

The second of these-distribution of flood awareness—is of relevance here. We explored the variance of awareness of flood risk within the populations in flood risk areas through secondary analysis (see Arber, 2001) of the 2001 At Risk Survey. One of the questions in this survey was: 'were you aware before now that your address is in an area which may be at risk of flooding?' Forty-nine per cent of residential respondents replied that they did not know that their property was in a flood risk area. We then explored whether any of the variables for which data had been collected in the survey could explain the lack of awareness. While it is recognised that this data was collected in 2001, it is not believed that the levels of awareness in the at-risk population have changed to any great extent. Indeed, the Environment Agency reported in 2005 that 41 per cent of at risk people nationally are unaware of their flood risk. $^{8}$

Neither gender nor employment status was found to be a significant factor in predicting awareness of flood risk, but flood experience, length of time at present address, tenure, age and class all appeared to have a important effect (see Table 1). Not surprisingly, those with flood experience (10.7 per cent of residents) were more aware of their risk-although 19 per cent of those who said that their property had been flooded claimed not to be aware of their flood risk. In addition, people who had lived in their present property for more than one year

${ }^{8}$ See http://www.direct.gov.uk/en/NI1/Newsroom/DG_10026588 (accessed 7 November 2007). 
were also likely to be more aware. Length of time spent in the area may also help to explain lower awareness of flood risk in younger age groups, where a lack of experience might be a factor. However, an increase in age (and presumably experience) does not perfectly predict greater awareness, since people over 65 years of age tended to be less aware of their flood risk. Social class was found to be another predictor of increasing flood awareness; there is a clear connection between awareness levels and social class, a relationship reflected among those owning their own property.

\section{Table 1}

Factors influencing awareness of flood risk to one's own property

\begin{tabular}{|c|c|c|c|}
\hline & $\begin{array}{l}\text { Percentage of people aware } \\
\text { that property is in a flood } \\
\text { risk area }\end{array}$ & Total (N) & Significance $^{a}$ \\
\hline \multirow[t]{2}{*}{ Gender } & $53 \%$ Males & 428 & n.s. \\
\hline & 49\% Females & 513 & \\
\hline \multirow[t]{2}{*}{ Property ever been flooded before } & $81 \%$ Yes & 100 & $* * *$ \\
\hline & $48 \%$ No & 834 & \\
\hline \multirow[t]{2}{*}{ Length of time at present address } & $27 \%$ Less than a year & 121 & $* * *$ \\
\hline & $55 \%$ More than a year & 820 & \\
\hline \multirow[t]{2}{*}{ Tenure } & $57 \%$ Owns & 634 & $* * *$ \\
\hline & $40 \%$ Rents & 305 & \\
\hline \multirow[t]{6}{*}{ Age } & $31 \%$ 16-24 & 49 & $* * *$ \\
\hline & $43 \% 25-34$ & 207 & \\
\hline & $55 \% 35-44$ & 193 & \\
\hline & $57 \% 45-54$ & 150 & \\
\hline & $56 \% 55-64$ & 141 & \\
\hline & $52 \% 65+$ & 201 & \\
\hline \multirow[t]{2}{*}{ Class } & $86 \%$ Class A & 29 & $* * *$ \\
\hline & $62 \% \mathrm{~B}$ & 160 & \\
\hline
\end{tabular}




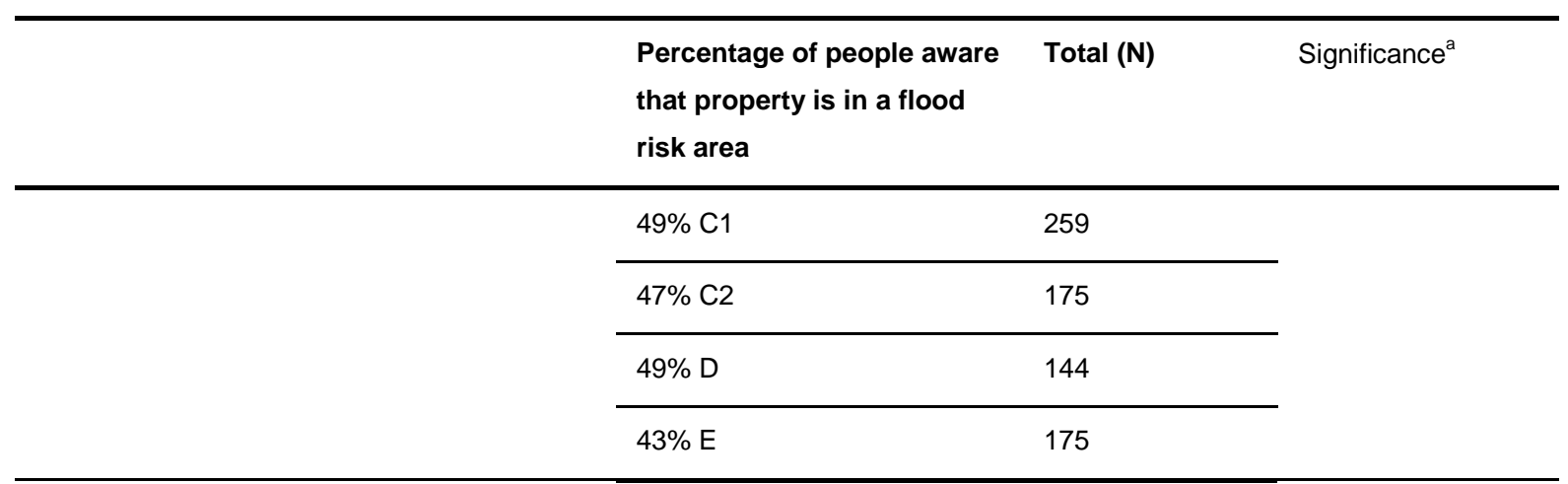

aChi Square test significance ${ }^{\star \star \star} p<0.001 ;{ }^{\star \star} p<0.01 ;{ }^{\star} p<0.05$

Flood awareness was also found to vary greatly between the Environment

Agency's eight regions (see Figure 1).

\section{Figure 1}

Flood awareness in the Environment Agency's eight regions

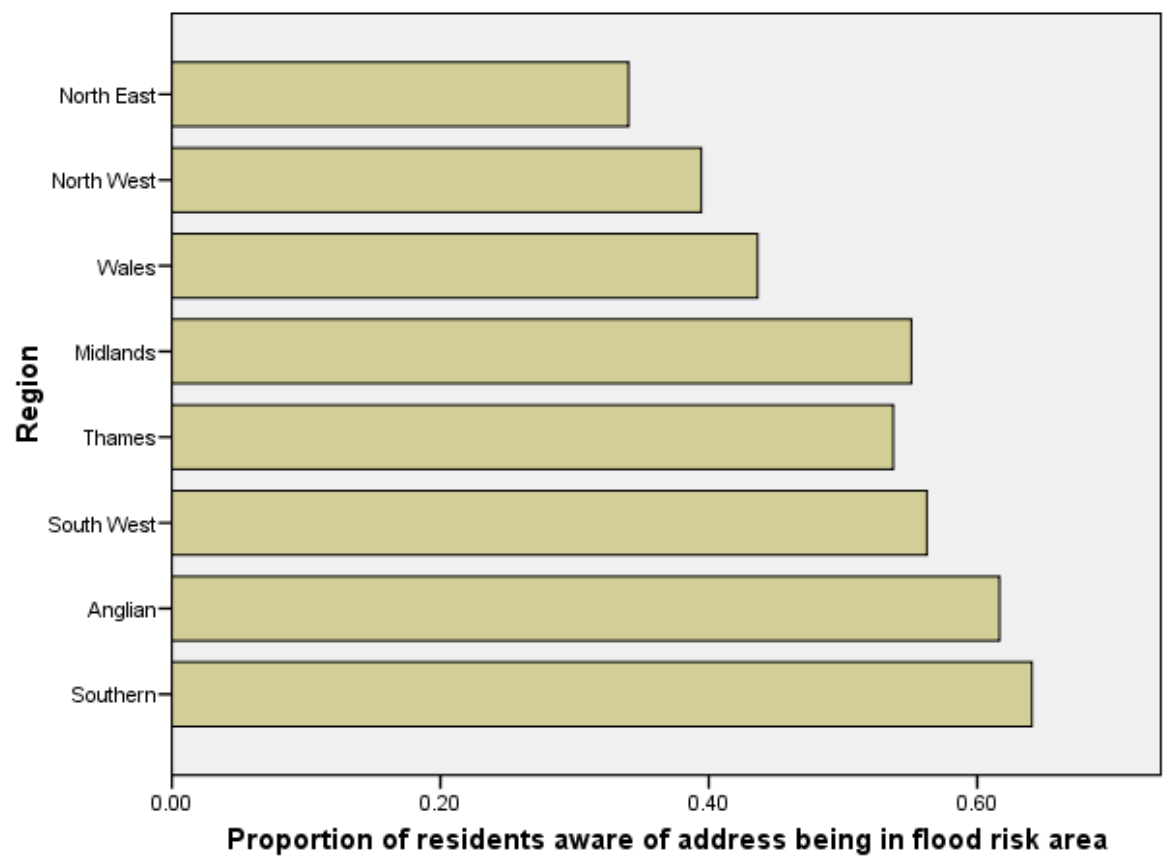

Source BMRB, 2001

These differences in awareness are partly accounted for by the influence of Environment Agency flood warning servicing in force at the time. 'Serviced' areas are those where the Environment Agency offers a full four-stage flood warning 
service, ${ }^{9}$ as defined in Local Flood Warning Plans. 'Non-Serviced' areas do not receive this full warning service. It is clear from Figure 2 that neither the North East nor the North West regions were Environment Agency serviced areas in 2001 and were also the least aware areas in England and Wales, although the least aware population was found to be in the non-serviced areas of the southwest. It is interesting that the whole of the Southern and Thames regions were Environment Agency serviced areas.

\section{Figure 2}

Serviced and non-serviced Environment Agency areas and flood awareness

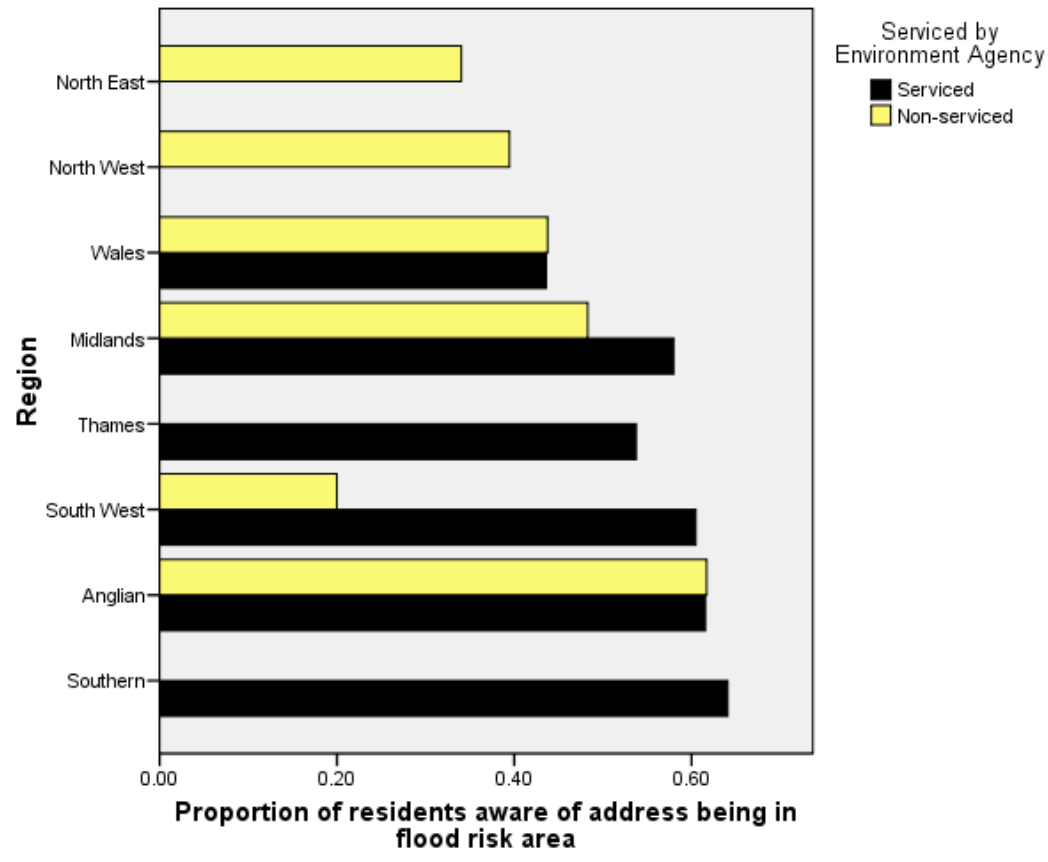

Source: BMRB, 2001

To explore which of the factors had the greatest influence on awareness, a logistic regression analysis was conducted that used the respondent's awareness (or lack of awareness) that his/her property was in a flood risk area as the dichotomous dependant variable. Table 2 shows the results.

\footnotetext{
${ }^{9}$ Flood Watch: Flood Warning: Severe Flood Warning: All Clear. See http://www.environmentagency.gov.uk/subjects/flood/1217883/1218065/1218107/ (Accessed $7^{\text {th }}$ November 2007)
} 


\section{Table 2}

Logistic regression analysis of the factors predicting the likelihood of awareness of flood risk

\begin{tabular}{|c|c|c|c|c|c|c|}
\hline & & $\begin{array}{l}\text { Model } 1 \\
\text { Exp(B) }\end{array}$ & Model 2 & Model 3 & Model 4 & Model 5 \\
\hline \multicolumn{7}{|l|}{ Area } \\
\hline & 1.00 Southern & $3.4^{\star \star \star}$ & $2.6^{\star \star}$ & 1.97 & 1.72 & 1.66 \\
\hline & 2.00 Anglian & $3.2^{\star \star \star}$ & $3.00 * \star \star$ & $2.58^{\star \star \star}$ & $2.56^{\star \star \star}$ & $2.59^{\star \star \star}$ \\
\hline & 3.00 South West & $2.5^{\star \star}$ & 1.96 & 1.46 & 1.29 & 1.31 \\
\hline & 4.00 Thames & $2.2^{\star \star \star}$ & 1.66 & 1.29 & 1.28 & 1.12 \\
\hline & 5.00 Midlands & $2.3^{\star \star \star}$ & 1.89 & 1.5 & 1.42 & 1.42 \\
\hline & 6.00 Wales & 1.6 & 1.22 & 0.93 & 0.87 & 0.84 \\
\hline & 7.00 North West & 1.3 & 1.25 & 1.09 & 1.03 & 1.06 \\
\hline & 8.00 North East & Reference Category & & & & \\
\hline \multirow{2}{*}{$\begin{array}{l}\text { If } \\
\text { Environment } \\
\text { Agency } \\
\text { serviced }\end{array}$} & Yes & & 1.33 & 1.53 & 1.65 & 1.69 \\
\hline & No & & $\begin{array}{l}\text { Reference } \\
\text { Category }\end{array}$ & & & \\
\hline \multirow{2}{*}{$\begin{array}{l}\text { If property } \\
\text { ever flooded }\end{array}$} & Yes & & & $4.27^{\star \star \star}$ & $4.06^{\star \star \star}$ & $3.85^{\star \star \star}$ \\
\hline & No & & & $\begin{array}{l}\text { Reference } \\
\text { Category }\end{array}$ & & \\
\hline \multirow{2}{*}{$\begin{array}{l}\text { How long } \\
\text { lived in } \\
\text { property }\end{array}$} & More than a year & & & $2.97^{\star \star \star}$ & $2.49^{\star \star \star}$ & $2.64^{\star * \star}$ \\
\hline & Less than a year & & & $\begin{array}{l}\text { Reference } \\
\text { Category }\end{array}$ & & \\
\hline \multirow[t]{2}{*}{ Tenure } & Owner occupier & & & & $1.73^{\star \star \star}$ & $1.61^{\star *}$ \\
\hline & Rents & & & & $\begin{array}{l}\text { Reference } \\
\text { Category }\end{array}$ & \\
\hline
\end{tabular}




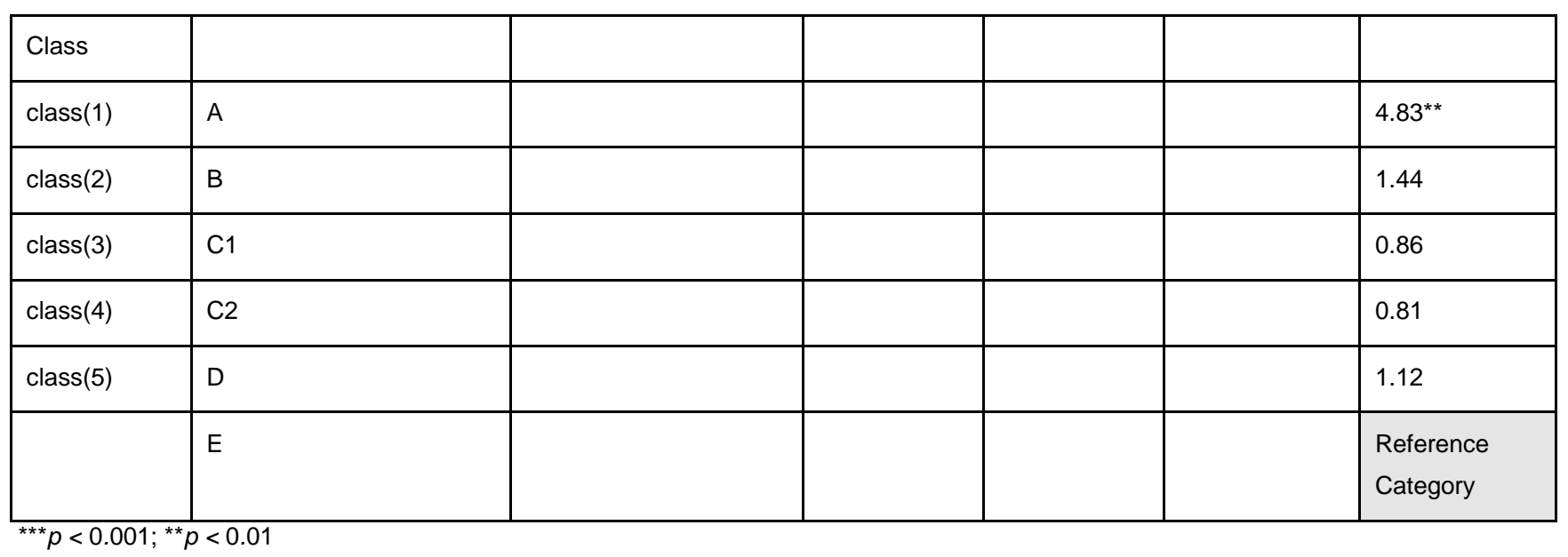

As expected, Model 1 of the logistic regression analysis demonstrates that the likelihood of being aware of flood risk differs significantly between the Environment Agency's eight regions, with the least aware North East being significantly different from areas south of the Midlands, although not significantly different from the North West or Wales. The introduction of Environment Agency servicing into the analysis (Model 2) clearly accounts for all area differences, except for those that between the least aware areas in the North and Anglian regions. Thus, those living in the flat, historically flood-prone Anglian region are three times more likely to be aware of their flood risk than those in the North East. The effect of being in an Environment Agency serviced area is not, however, a significant predictor.

Model 3 introduces two flood experience variables: experience and length of residence. Both are significant factors in predicting flood awareness, with people with experience being more than four times more aware than those with no experience, and longer-term residents (more than one year) being nearly three times more aware of their flood risk. The impact of flood experience does not significantly alter area differences: the Anglian region remains significantly more aware than all of the other regions. This suggests that some other factor must account for high levels of awareness in that region. 
Model 4 adds tenure to the model. We have already seen that those in rented properties are less aware of flood risk than those who own their property. By adding this variable to the model, we aimed to establish whether it accounted for the area difference. The results reveal that owner-occupiers are nearly twice as aware as tenants, yet the introduction of this variable does not significantly affect area level awareness, implying that tenure differences by area do not explain the difference between the Anglian and other regions. Introducing tenure to this model does, however, impact on the effect of flood experience and longer residence on the likelihood of awareness. This is not surprising since owneroccupiers tend to reside in a property for longer than tenants do and are therefore more likely to have experience of flooding.

The final model, number 5 , introduces class to the model. The class gradient seen in the bivariate analysis manifests itself again here, with significant differences between classes. In fact, class is a very significant predictor of flood risk, with those in class $A$ being nearly five times more aware of their flood risk than those in class $\mathrm{E}$. The introduction of class to the model is accompanied by a reduction in the effects of flood experience and tenure on likelihood of awareness, although these variables remain significant in predicting flood awareness. Age was not found to be a significant predictor of awareness, and was consequently excluded from the model.

Overall, therefore, it is clear that social class has the most influence on predicting awareness of flood risk, followed by flood experience and then length of residence. The significant area difference in flood risk awareness between the Anglian region and the rest of England and Wales has yet to be explained.

\section{Accounting for the lack of awareness of flood risk}

Whereas quantitative analyses provide insight into structural and demographic factors that may affect levels of awareness, qualitative analyses offer insights into 
how people themselves account for their lack of awareness of their property's risk of flooding.

Most of the data discussed here, as noted above, is drawn from the Flood Warning for Vulnerable Groups project, which involved interviews with people affected by the flood events of 2000. At the time of the interviews, therefore, all were clearly aware that their property was at risk of flooding, although many claimed that prior to the floods of 2000, they had not known, or thought, that their property was at risk. The following sections outline the most common explanations of respondents of their previous lack of awareness. It is important to note that respondents did not necessarily provide just one explanation but often put forward a variety of those presented below.

One of the most striking findings of this project was that very few of our interviewees had considered their property to be at risk of flooding and many had not even been aware of any local risk - the exception being participants who lived in Bewdley (see below). Some participants perceived their locality to be completely risk-free as far as flooding was concerned, and almost all of them appeared to view their own home as invulnerable, apparently believing that 'it won't happen to us'.

\section{Acknowledging and explaining the lack of awareness of risk to property}

As outlined above, the Environment Agency's perspective on public awareness is based on an implicit deficit model of knowledge, which depicts those unaware of the flood risk as lacking correct information about the danger. Many of our respondents concurred with this and thus implicitly accepted the Environment Agency's viewpoint. Their acknowledged lack of awareness was justified, however, through the highlighting of various deficiencies in the provision of information on the risk and of the invisibility of flood risk.

Information problems 
One common way of explaining a lack of awareness of flood risk is by referring to problems connected with the provision of risk-related information. Some respondents claimed to have had no information about the risk status of their property prior to the flood event. Others had access to information, but complained that it was unclear or difficult to understand.

A finding common to both the qualitative and the quantitative components of our research is that 'new' residents appeared particularly unaware of any flood risk to their homes before the flooding in the autumn and winter of 2000. Two such groups participated in the first research study: one from Bewdley, a town situated on a major river with a well-known and widely documented history of flooding; and the other from Woking, a town with no such history (even though flooding had occurred there some 30 years beforehand). Whereas the members of the Bewdley group claimed to be well aware of potential (and previous) flooding in the area even before moving there, participants from Woking said that they had no knowledge whatsoever that they were buying homes that lay on a floodplain.

Male: I knew about floodplains but I didn't imagine for one minute that where we're located was on one.

—New residents: Woking. Flood Warning for Vulnerable Groups project.

New residents often underscored that their lack of knowledge was not due to apathy, detailing the enquiries that they had made about flood risk before buying their properties. One man reported that he had even approached the Environment Agency for a full flood history of the local river. Very few of them said that they had been alerted to any risk, even in the obviously flood-prone locality.

Male: We checked everything but it didn't alert you to the fact it was a floodplain ... there was nothing to tell us it was on a floodplain. I wouldn't have bought the house if l'd known ...

—New residents: Woking. Flood Warning for Vulnerable Groups project. 
Female: We were certainly not expecting it to flood what with the enquiries we had made; we were told it didn't flood ...

—New residents: Bewdley. Flood Warning for Vulnerable Groups project.

Even in cases where a property had a known flood history, as uncovered by legal searches for example, this was not necessarily revealed to the prospective purchasers by the professionals involved:

Male: [My solicitor] said [the flooding did] show up in the search but it was in 1968, so he said he never mentioned it because it was a long time ago and not worth worrying about.

—New residents: Woking. Flood Warning for Vulnerable Groups project.

Female: We knew nothing at all ... and searches, you only have to give the last 20 years history and because [that] didn't include the 1968 [flood] we were unaware of anything.

Parents: Woking. Flood Warning for Vulnerable Groups project.

Lack of official information was also the explanation given for low levels of flood risk awareness among those interviewees belonging to a minority ethnic group. Even though the Environment Agency had apparently targeted their locality, none of them was aware that printed information was available in their own language and not one of them was acquainted with the Environment Agency's flood warning system.

Some respondents complained that although information about the risk to their property had been available, it was confusing or difficult to understand because of the technical language adopted. The Environment Agency uses terms derived from statistical probability to describe differing degrees of flood risk. This technical jargon, easily comprehended by 'experts', is not always clear to lay persons. There was confusion, for example, about the meaning of a ' 1 in 50 year' event: 
Female: It was the first thing I asked ... when we went round [the house] and he said 'every 50 years' but he didn't say which 50 years did he? ... I was 75 so it didn't worry me!

—OIder people: Bewdley. Flood Warning for Vulnerable Groups project.

Female: I think somebody was quoted as saying a once in 50-year flood but in our case it was twice in five months.

—Parent: Skinningrove. Flood Warning for Vulnerable Groups project.

The invisibility of flood risk

A common assumption is that properties at risk of flooding lie close to a river or to the sea, and thus the possibility of flooding should be evident to residents. Some of our interviewees, however, explained their lack of knowledge by referring to the absence of any visual clues that might have alerted them to the presence of a local flood risk. The dangers associated with rising ground water levels, small streams and so on were simply 'invisible' in many instances. In Woking, the very name of one watercourse-the Hoe Stream-as well as its small size, belied any possible threat of flooding:

Male: It's a stream, innit?

Male: Supposed to be.

Male: Yeah, it's got two inches of water in it ...

Male: In fact, I didn't even know, this is how sad I am, I didn't even know there was a bloody river. That was a surprise. I knew the hump back bridge, I go over it every day, but I didn't know there was a river in that proximity. I wouldn't have bought the house had I known that the house was at risk at all from any flood.

—New residents: Woking. Flood Warning for Vulnerable Groups project.

Visual clues provided by geographical features can also cause confusion. This was particularly the case in Skinningrove, a coastal village in North East England. Residents said that they had believed that any flooding would be because of the sea, affecting only the row of houses on the seafront; the beck itself had never given cause for concern, even when running high. 
Female: If anything, I suppose it's always been 'hang on, we may be flooded from the sea' but we've never felt a threat with the beck. My husband's lived down here all his life and has never been flooded, never felt at risk.

—Parent: Skinningrove. Flood Warning for Vulnerable Groups project.

At other research sites, although the watercourse was very obvious, the associated risk remained invisible in certain cases. These instances mostly involved people who had moved from inland to retire at a riverside location near the coast. They saw rivers as tranquil and scenic and appeared to have no appreciation of any concomitant risks, never imagining that they 'could come up and bite you'. Ignorance of the threat was accounted for here in terms of having little or no experience of rivers, let alone of flooding; such people were simply unable to comprehend the possible dangers of living in a riverside property.

Male: I didn't understand the river; I thought the river was for fishing and things like that ... Nobody told me.

Female: But when you see it in the summer, the river is low and the bank looks so high ...

Male: Oh, it's lovely.

Female: You think it's never going to come up.

-Older people: Iford. Flood Warning for Vulnerable Groups project.

\section{Local experience of flood risk}

So far, we have seen that a lack of awareness of flood risk to property is sometimes explained by a dearth of information on the danger or by making reference to the invisibility of the threat. However, in a great many instances, we found that people had considerable knowledge of the local area and understanding and experience of the flood risk there, yet still had not considered their own property to be vulnerable. Experience of relatively minor past flood events may lead people to underestimate the likelihood and impact of a major event (Scanlon, 1990). This was clearly the case with the major floods of 2000. Local experience of previous flood events was a common reason for why people had not considered their own property to be at significant risk. Explanations drew 
on factors such as the length of time since the last major flood, the 'usual' geographical extent of local flooding, and experience of minor flooding within people's homes. People offering such explanations are not accurately depicted as having been unaware that their property was in an area at risk of flooding, rather we might tend to view them as having been previously relatively 'unconcerned' about this risk.

\section{Time}

In some of our research sites, the last flood event before the Millennium floods occurred some 20 or 30 years prior. Several people knew of older residents whose properties had been affected, but decades without further incident had allayed many people's fears, engendering a feeling that nothing similar would recur. Where a considerable time had elapsed since the last episode, people said they simply believed that 'it won't happen again'.

Male: I've lived in and around Bewdley for thirty years-in one, two, three properties-and then in February we moved from the High Street down ... to our dream cottage. It hadn't been flooded for 50 years and we thought 'well this must be a good thing', and then in November 2000 it flooded.

—New residents: Bewdley. Flood Warning for Vulnerable Groups project.

Female: My parents didn't even remember; they were living in Woking then but they don't remember the flood.

-Parents: Woking. Flood Warning for Vulnerable Groups project.

Area

Many respondents said that although they knew that the locality was vulnerable to flooding, they had not expected their own property to be affected. Several people cited the distance between their home and the watercourse as their reason for feeling safe, even though the land itself may lie within the indicative floodplain. Properties 'far from the river' were not expected to flood: 
Female: We're quite far from the river as you know. Obviously, Mwrog Street is renowned for flooding because it's been flooded a few years ago, but we're not even by the river. I know it's quite flat where we are, but you don't expect that amount of water really.

Female: I mean we're three, two fields away so you don't expect it.

-Parents: Ruthin. Flood Warning for Vulnerable Groups project.

Others recounted their detailed local knowledge of the usual extent of flooding, emphasising that they could not have expected their own property to flood:

Male: Most years it's minor but it floods, certainly on to the road here.

Male: I think you're aware if you've lived in Severnside you're often flooded.

Male: Yes, yes but not [the south side].

Male: That's right because I knew it flooded particularly at the top end towards the bridge.

Female: We didn't think we were going to flood at all because according to our surveyor even in 1947 that property didn't flood so we were not expecting it.

—New residents: Bewdley. Flood Warning for Vulnerable Groups project.

The fact that floodwaters appeared from time to time and did not harm property also seems in some way to have desensitised people to any greater degree of risk:

Female: It's flooded the road before but it's never been in the properties.

Male: It bursts its banks all the time doesn't it?

Male: All the time we've lived here, we've seen the common flood and the water drain away again ... but what happened to us two years ago was so out of character.

-Parents: Woking. Flood Warning for Vulnerable Groups project.

Several people appear to have drawn on local flood-related knowledge before entering into property-buying decisions. A life-long resident of Bewdley, who remembered the severe floods of 1946 and 1947, affecting the lower part of the lane she now lives in, deliberately chose to buy a house on higher ground: 
Female: When the floods came up when I was a child, we used to live opposite the bottom school and [the water] was always in the school. They emptied all those houses ... and built new houses up the hill for people to go into. Then the Preservation Society said it was wicked to take the houses down, it was a beautiful little street, so they did them up and mine was one ... The builder offered me one further down 12 months before I moved, but I knew and I said no. I wouldn't live any further down; if I couldn't have one up at the top that was it. I never dreamt that it would get as far as me. We've never had a flood, not like that ... I never expected it. -Older people: Bewdley. Flood Warning for Vulnerable Groups project.

\section{Property}

There is evidence too that people were not only reassured by thinking that flooding was contained within other parts of their local area, but were often cushioned by a history of very minor flooding within their own homes. We found people whose cellars or gardens had flooded, suffering little or no damage, and who therefore believed that nothing worse could happen.

\footnotetext{
Female: Half of me was [aware] and half of me wasn't. We knew there was a risk of flooding but because it was only the cellar that had flooded in the last 10 years or so it wasn't expected.

—New residents: Bewdley. Flood Warning for Vulnerable Groups project.
}

Male: But it was only very minor flooding ... the property itself had not flooded since 1947.

—New residents: Bewdley. Flood Warning for Vulnerable Groups project.

Female: The most I got was to the doorstep.

—Parent: Ruthin. Flood Warning for Vulnerable Groups project.

\section{Denial}

Perhaps the most disturbing of the explanations given for the lack of awareness prior to the flood event is what we might term the ostrich effect. Some people admitted to a complete lack of concern about personal risk of flood, even though they were in possession of knowledge or experience that could enable rather 
than hinder awareness. Some participants, for example, admitted to being fully aware of the dangers of flooding in their locality, and had family or friends nearby whose homes had been flooded on several occasions. In many cases, however, they seemed to put that knowledge to one side. One older couple bought their home knowing that their daughter's house a stone's throw away had already flooded, whereas another woman recounted how her parents had exchanged contracts on a house while the watercourse was on flood alert:

Female: now how mental is that, eh?

—Parent: Ruthin. Flood Warning for Vulnerable Groups project.

Female: No, it never entered our head really, yet my daughter had [been flooded] across the courtyard, and yet we never consciously thought about floods before. But it didn't put us off [buying], we never thought about it.

-Disabled older couple: Bewdley. Flood Warning for Vulnerable Groups project.

Our fieldwork for the Public Response to Flood Warning project involved interviewing people living in areas designated as at risk of flooding, but where local floods had not recently occurred. Denial was not an uncommon response among this group:

Female: I've lived in Eastbourne for a long time and ... although I know [this area] had flood risks I do feel like I haven't seen it yet so let's bury my head.

-Owner-occupier: Eastbourne. Public Response to Flood Warning project.

Some respondents claimed that even if a severe flood warning were to be issued-with the Environment Agency declaring that severe flooding is 'expected, with imminent danger to life and property; act now!'- -they would still ignore the Agency's advice:

Male: I'd still be burying my head in the sand and thinking it won't happen.

—Disabled man: Eastbourne. Public Response to Flood Warning project.

\section{Rejection of 'at-risk' status}


Thus far, we have examined a variety of explanations offered by respondents for their lack of awareness that their property was at risk of flooding. These participants implicitly accepted the Environment Agency's designation of their property as located in a flood risk area. Not all of those identified as living in floodplains accept this status, however. Flood researchers regularly encounter respondents who deny that they live within the floodplains identified by the Environment Agency. Indeed, some actively campaign against the inclusion of their properties within those floodplains.

The Environment Agency defines households as being at risk of flooding if their homes are located within the indicative floodplains. It may seem obvious that residents within the floodplains are most at risk of flooding and comprise the 'atrisk' population, but measurement of the extent of the floodplains and quantification of the likelihood of floods are contentious exercises, which are exacerbated by many factors, ranging from climate change to the involvement of the insurance industry.

The original 'indicative floodplain maps' were not very accurate. In 2004, the Environment Agency, in collaboration with insurers, created more accurate maps using the latest technology and hydrological modelling, which claimed to provide 'the best currently available information, using national consistent data'. ${ }^{10}$ The maps not only identify 'risky places', but also are used to identify the 'at-risk' population within their boundaries.

However, there are acknowledged problems with the flood maps. Notably, they have been criticised for not showing the 'true' extent of the flood risk. Risk may be underestimated, as in the case of flooding caused by inadequate storm-drains or groundwater and surface water run-off, and overestimated where flood defences or

${ }^{10}$ See the website of the Environment Agencyhttp://www.environmentagency.gov.uk/subjects/flood/826674/829803/858477/862632/?version=1\&lang=_e\#3 (accessed 12 May 2006). 
local topography have not been accounted for. In addition, the Environment Agency's own literature concedes that flood maps "cannot provide detail on individual properties'." Thus, the maps can lead to a potentially problematic miscalculation of risk.

Some people designated as living in at-risk areas have suggested that, quite simply, the Environment Agency's maps are wrong:

I don't want to be ignorant but it is absolute trash to say that this property is at risk of being flooded. I have lived in Upton-upon-Severn all of my life and I am 84 years old, and this area has never been flooded in that time: and I am saying that with 30 years experience in the fire brigade. Whoever put this address on the at-risk register was very wrong, if the flooding ever got to this area Upton would not exist. -Post Event Survey 2001, verbatim responses.

Others have pointed to particular features of their location (on a hill) or their property (high in a block of flats) that make the suggestion of at risk of flooding seem, at best, unlikely.

Some of our respondents drew attention to conflicting or insufficiently precise information regarding floodplains. Indicative floodplain maps are now available from insurance companies, as well as from the Environment Agency, and our

\footnotetext{
${ }^{11}$ See the website of the Environment Agency http://www.environmentagency.gov.uk/subjects/flood/826674/829803/858477/862632/?version=1\&lang=_e\#3 (accessed 12 May 2006).
} 
data highlights several instances of people accessing different information on the position of their own homes:

Female: The flood areas are all different for every insurance company [compared] to what the Environment Agency says ... with the xxxl was told we're not in the flood area but with xxx we were ... It really needs to be clarified whether they're in a danger area or not.

—Disabled woman: Eastbourne. Public Response to Flood Warning project.

Some implied conspiracy between the Environment Agency and insurers:

Female: But as soon as you give your postcode, they immediately know you're in a high risk flood area.

Female: Even if you're not, I notice on the list of roads that you gave us one of those was ... literally up on the Downs; how can you possibly flood up there? ... And yet as far as the insurance companies are concerned, all they have is your postcode ... the Environment Agency's stated that you are in that area.

Male: And in the harbour there are seven-storey blocks to flood so if you live in the top of the storey ... you're still going to be penalised.

-Owner-occupiers: Eastbourne. Public Response to Flood Warning project.

\section{Discussion and conclusions}

In this paper, we have considered only one aspect of public flood awareness: whether people know that their property is in an area that is at risk of flooding. As we have acknowledged, flood awareness is multifaceted, and our analysis provides some useful pointers for future research and for flood warning practice.

The quantitative analyses we conducted indicate that social class, flood experience, length of residency, and the region in which people live all impact significantly on levels of flood awareness. The finding that flood awareness is related to social class, with those in the lower strata being less likely to 
demonstrate awareness, reinforces concerns about environmental inequalities in relation to flood risk. Recent research (Walker, Fairburn and Smith, 2003; Walker et al., 2006; Fielding, Burningham and Thrush, 2005b) indicates that more deprived populations, and those belonging to lower social classes, are more likely than less deprived populations to be living in zones at risk of flooding. If these people are also less likely to be aware of the risks that they face, they may be considered as doubly vulnerable. Possible explanations of lower levels of awareness among those belonging to lower social classes might be lower levels of education, and/or inappropriate information provision or a lack of participation in awareness-raising activities. Further research is needed, however, to explain this phenomenon fully. Such research is important as it could help with the development of appropriate risk communication strategies.

We also found that levels of flood risk awareness varied between the Environment Agency's regions, with those in Anglian region having significantly higher levels of awareness than respondents in the remainder of England and Wales. The existence of such regional differences, despite uniform national awareness campaigns, points to the influence of local circumstances and local flood awareness campaigns and warning strategies. Factors such as local demography and community characteristics, specific features of local flood awareness campaigns, and relationships with local Environment Agency staff may all play a part. Understanding how such variables influence awareness levels could make an important contribution to efforts to improve strategies for heightening public awareness across England and Wales

Both our quantitative and qualitative analyses reinforce the significance of flood experience coupled with length of residence in raising awareness of the risk (see Cutter et al, 2003; Scanlon, 1990). The problem is how to raise awareness without people having to go through the trauma of an actual event. As the Environment Agency has recognised, this is a particular problem for areas where 
the probability of flooding is low but the consequences of such an occurrence would be high (Shaw et al., 2005).

Our research also illustrates that having experience and knowledge of local flood risk does not necessarily prepare people for flooding of their own property. As Green, Tunstall and Fordham (1991, p. 231) note, 'those who have been flooded have generally developed a model of the causes of flooding which they can use to predict the likelihood of flooding in the future'. These authors go on to state that lay assessments of flood risk tend to embody an expectation that future risk will be a replication of the past; an assumption that is likely to lead to an underestimation of the impact of rare, extreme flood events. Thus the problem is not only, or even principally, that people lack awareness that their property lies in an area at risk of flooding, but that they know this and are unconcerned or in denial. As we have shown, any experience of local flooding, whether first or second hand, is used to evaluate the risk to one's own property, and flood awareness campaigns are likely to be interpreted in relation to this experience. Consequently, the Environment Agency's construction of the problem as one of a lack of awareness of local flood risk, with the solution being to raise awareness levels, is not entirely appropriate. The challenge is also how to persuade people with extensive experience of local flooding, but who believe that their own property will not be affected, to take preparatory action.

People's reluctance to accept that their property is at risk can sometimes be explained by reference to economic interests. Acknowledging that one's home may be flooded may affect the insurance and the value of the property, which householders are likely to want to avoid. This explanation, however, is not sufficient on its own. It draws on ' a tacit instrumental, rational-choice model of risk and human behavior' (Horlick-Jones, 2005, p. 255), which is at odds with the opinion that risks are viewed within particular contexts and are 'by necessity associated with plural rationalities' (Horlick-Jones, 2005, p. 257). Another strand of rationality that comes into play is psychological attachment to the home. Sime 
(1997) and McCarthy (2004) remind us that home constitutes an emotional, not just an economic, investment, and note that risk denial before flooding has been related to place identity and attachment [rephrase]. As Scanlon (1990, p. 235) notes, 'researchers in all parts of the world have found a remarkable capacity to ignore threats'. People may disbelieve or deny the threat to their home as to accept it is psychologically unsettling. Sime also points to the need for 'flood warning risk communication ... to address the context of people's lives and the relationship they have to their home, community and landscape' (Sime 1997, p. 171).

Respondents who admit to having been unaware of their flood risk status before experiencing extreme flooding might be seen as being in a somewhat embarrassing position, and therefore keen to find explanations for their lack of awareness. We identified a variety of ways in which respondents' accounts fend off pejorative suggestions about culpable ignorance, and explain and justify their knowledge and beliefs about the risk faced. First, we found that while some people concurred with the Environment Agency's description of themselves as unaware and lacking knowledge, they placed the blame for this situation on those whom they saw as responsible for providing information. Information provision is important but it needs to be informed by the growing literature on public participation and involve communication of environmental and risk information. Bell, Gray and Haggett (2005, pp. 471-472) suggest that:

The only credible form of information provision is grounded in trust that is built through two-way communication embedded in an inclusive participatory process.

Information will always be negotiated in the context of experience, local knowledge and trust in those providing that information. Once again, this indicates the need for risk communication strategies that take account of local circumstances and perspectives, and seek to engage people in a process of building local awareness. Taking local perspectives of flood risk seriously, and 
involving people in developing and delivering local strategies by making creative use of informal systems and social networks, have been recognised for many years as important factors in achieving better preparedness for floods (Shaw et al., 2005; Parker and Handmer, 1998; Parker 2000, Handmer, 2000)

Another way in which interviewees explained their lack of awareness of flood risk was in reference to the invisibility of the threat. Invisibility is identified by Beck (1992) as being one of the defining characteristics of risk within contemporary 'Risk Society'. It is clear, however, that invisibility is not just a feature of the 'new' risks that concern Beck, but may also apply to traditional or 'natural' risks such as flooding. Far from making this risk more worrying in the way that Beck (1992, p. 73) imagines, the invisibility of flood risk seems to lead to it being ignored. Analysis of lay knowledge of flood risk (McCarthy, 2004) points to the importance of visual cues (including the height of the water) in local assessments of risk. The ability to recognise and read such cues takes time and is a skill that new residents in particular are likely to lack. There may be scope to address this by building on traditional methods of making flood risk locally visible, for instance by marking the level of past flood waters on prominent buildings.

Taken in tandem with our comments on the way in which local flood experience informed peoples' assessments of risk to their own property, this highlights the importance of recognising that risks that seem apparent from the outside may not be so obvious to those on the ground. Sources of flood risk may be locally invisible, or the threat of flooding may seem irrelevant in the context of other risks or benefits associated with living close to a river or to the sea. Far from simply being a risk, living close to water is often viewed as desirable (House and Fordham, 1997) and may improve property values. To understand people's perspectives on flood risk it is imperative that the risks are viewed in the context of evaluations of local life and the local environment. This is an important area for future research. Much of the existing work on flood awareness and understanding focuses only on people's knowledge, understanding and concerns 
about flooding, not on how these factors figure within broader evaluations of local life. This is largely because the bulk of work on this topic in England and Wales has been funded by the Environment Agency, which has a specific interest in flooding.

Alongside acceptance of lack of knowledge of flood risk, and the belief that one's property would be unaffected, we found people who completely rejected the Environment Agency's designation of their property as being at risk. The outright rebuff of the external assessment of risk draws attention to the subjectivities, uncertainties and assumptions inherent in any mapping of risk. It reminds us that multiple risk perspectives always exist and that an assumption that there is only one correct and objective view is likely to be counterproductive.

In conclusion, top-down campaigns that aim to convince people that their property is at risk are unlikely to succeed on their own. As we have shown, the problem is often not simply a lack of awareness of local risk, as is suggested by the Environment Agency, but rather an assessment of such risk that underestimates the impact of rare, extreme events. We concur with earlier studies in underlining the importance of engaging with local perspectives on risk and making local people part of novel and interactive processes of awareness raising. We also argue for more contextual research that explores local perspectives on flooding within broader evaluations of local life.

\section{Correspondence}

Dr. Kate Burningham, Centre for Environmental Strategy, University of Surrey, Guildford GU2 7XH, UK. Telephone: 01483 686688; e-mail:

K.Burningham@surrey.ac.uk.

\section{References}

Arber, S. (2001) Secondary Analysis of Survey Data. In: Gilbert, N. (Ed) Researching Social Life (2nd edition), Sage, London. pp. 269-286. 
Beck, U. (1992) Risk Society Towards a New Modernity. Sage, London.

Bell, D., T. Gray and C. Haggett (2005) 'Policy, Participation and the "Social Gap" in Wind farm Siting Decisions'. Environmental Politics. Vol. 14, No. 4. pp. 460-477.

Brown, P. (1993) 'When the Public Knows Better: Popular Epidemiology'. Environment. Vol. 35, No. 8. pp. 17-41.

BMRB (2001) At Risk Survey, BMRB/1154-898, BMRB International, London.

Burningham, K. and D. Thrush (2001) Rainforests are a long way from here: The Environmental concerns of disadvantaged communities. Report for the Joseph Rowntree Foundation. York Publishing Services, York.

Burningham, K. and D. Thrush (2004) 'Pollution concerns in context: a comparison of local perceptions of the risks associated with living close to a road and a chemical factory'. Journal of Risk Research. 7 2. pp. $213-$ 232.

Burningham, K., J. Fielding, D. Thrush and K. Gray (2005) Flood Warning for Vulnerable Groups. Report for the Environment Agency, Science Summary. SC990007/ss. Environment Agency, Bristol

Cutter, S., Boruff,B. and Shirley, L. (2003) Social Vulnerability to Environmental Hazards. Social Science Quarterly 84 (2) pp.242-261.

Fielding, J., K. Gray, K. Burningham and D. Thrush (2005a) Flood warning for vulnerable groups: secondary analysis of flood data. R\&D Report. W5C018/2. Environment Agency, Bristol.

Fielding, J., K. Burningham and D. Thrush (2005b) Flood warning for vulnerable groups: measuring and mapping vulnerability. R\&D Report. W5C-018/4. Environment Agency, Bristol.

Fielding, J., K. Burningham, D. Thrush and R. Catt (2007) Public Response to Flood Warning. R\&D Report SC020116. Environment Agency, Bristol.

Green, C.H., S.M. Tunstall and M.H. Fordham (1991) 'The Risks from Flooding: Which Risks and Whose Perception?' Disasters. Vol. 15, No. 3. pp. $227-$ 236. 
Handmer, J. (2000) 'Are flood warnings futile? Risk communication in emergencies'. The Australasian Journal of Disaster and Trauma Studies. 2. http://www.massey.ac.nz/ trauma/issues/2000-2/handmer.htm (accessed 10 May 2006).

House, M. and M. Fordham (1997) 'Public Perceptions of River Corridors and Attitudes towards River Works'. Landscape Research. Vol. 22, No. 1. pp. 25-44.

Horlick-Jones, T. (2005) 'Informal logics of risk: contingency and modes of practical reasoning'. Journal of Risk Research. 8(3). pp. 253-272.

Irwin, A. (1995) Citizen Science: A Study of People, Expertise and Sustainable Development. Routledge, London.

Irwin, A. and M. Michael (2003) Science, Social Theory and Public Knowledge. Oxford University Press, Maidenhead.

MAFF (Ministry of Agriculture, Fisheries and Food) (1993) Strategy for Flood and coastal defence in England and Wales. Publication PB 1471. MAFF, London.

McCarthy, S. (2004) Definition and experience of flooding: residents' and officials' perspectives. PhD thesis, Department of Sociology, University of Surrey.

Parker, D. (2000) Flood Warning Dissemination and Response: Lessons from International Research. Publication no. 0437. Flood Hazard Research Centre, Middlesex University.

Parker, J. and J. Handmer (1998) 'The role of unofficial flood warning systems'. Journal of Contingencies and Crisis Management. Vol. 6, No. 1. pp. 4560.

Phillimore, P. and S. Moffatt (1999) 'Narratives of insecurity in Teesside: Environmental politics and health risks'. In J. Vail, J. Wheelock and M. Hill (eds.) Insecure Times: Living with Insecurity in Contemporary Society Routledge, London. pp. 137-153. 
Ramsbottom, D. (2003) Guide to the Management of Floodplains to Reduce Flood Risks. Stage 1: Development Draft. Defra/Environment Agency R\&D Technical Report FD2010/TR. Environment Agency, Bristol Scanlon, J. (1990) 'People and Warnings: So Hard to Convince'. In J. Handmer and E.C. Penning-Rowsell (eds.) Hazards and the Communication of Risk. Gower Technical, Aldershot. pp 233-245.

Shaw, J., S. Cudmore, D. Collier, D. Reed, A. Antonelli, R. Genna, \& J. Berman (2005) Improving flood warning awareness in low probability and mediumhigh consequence flood zones. R\&D Technical Report W5-024. Environment Agency, Bristol

Sime, J. (1997) 'Informative flood warnings: Occupant response to risk, threat and loss of place'. In J. Handmer (ed.) Flood Warning: Issues and Practice in Total System Design. Flood Hazard Research Centre, Middlesex University. pp. 155-175.

Sturgis, P. and N. Allum (2004) 'Science in Society: Re-evaluating the deficit model of public attitudes'. Public Understanding of Science. 13(1). pp. 5575.

Thrush, D., K. Burningham and J. Fielding (2005) Exploring flood-related vulnerability: a qualitative study. R\&D Report W5C-018/3. Environment Agency, Bristol.

Walker, G., J. Fairburn and G. Smith (2003) Environmental quality and social deprivation. R\&D Technical Report E2-067/1/TR. Environment Agency, Bristol.

Walker, G. et al. (2006) Addressing Environmental Inequalities: Flood Risk. Environment Agency Science Report SC02006/SRI. Environment Agency, Bristol Wynne, B. (1991) 'Knowledges in Context'. Science, Technology and Human Values. Vol. 16, No. 1. pp. 111-121.

Wynne, B. (1996) 'May the sheep safely graze? A reflexive view of the expert-lay knowledge divide'. In S.M. Lash, B. Szerszynski and B. Wynne (eds.) Risk, Environment and Modernity: Towards a New Ecology. Sage, London. pp. 44-83 